\title{
Soil Erosion by Water and Climate Change, How Can Reaching the Sustainability in European Mediterranean Basin
}

\author{
António Canatário Duarte D,2,3* $^{1,2}$ \\ ${ }^{1}$ School of Agriculture, Polytechnic Institute of Castelo Branco, Portugal \\ ${ }^{2}$ Research Centre GEOBIOTEC, University of Beira Interior, Portugal \\ ${ }^{3}$ Research Centre IPCB-CERNAS, Polytechnic Institute of Castelo Branco, Portugal
}

Submission: February 01, 2022; Published: February 07, 2022

*Corresponding author: António Canatário Duarte, Polytechnic Institute of Castelo Branco, Av. Pedro Álvares Cabral, No 12, 6000-084 Castelo Branco, Portugal

\begin{abstract}
Water erosion, and the consequent soil loss, represents a cost to agriculture as it means loss of productive land, nutrients and organic matter as well as environmental degradation of water resources downstream. This cycle of unsustainability will lead, to a physical desertification of places accompanied by a human desertification. It is essential to understanding the process, the influence of each factor that it depends, for the adoption of more effective actions for its prevention. The randomness of the Mediterranean climate can determine years with higher volumes of precipitation that correspond to more erosive events, and driest years with the occurrence of fewer erosive events, but with expanded erosive potential in some of them. This climatic pattern will be aggravated in climate change scenario, which correspond the forecast less annual rainfall volume, but concentrated in extreme events. The runoff will be more or less powered, depending on how manifest other factors that influence the erosive process, namely, vegetation, soil, topography, and agricultural practices of farmers.
\end{abstract}

Keywords: Soil erosion by water; Mediterranean climate; Climate change scenario; Prevention and mitigation measures

\section{Introduction}

Erosion is one of the processes that are part of natural systems, being, at the same time, responsible for the impoverishment of soils in some areas, and for the occurrence of the best areas of soil dedicated to agricultural activity, such as the alluvial deposits. In this case, it is denominated geological erosion, or that which occurs without human intervention in the exercise of multiple activities, and in which the natural system has the capacity to restore successive balances [1]. The intensification of agricultural activity and the emergence of other degrading activities, the non-compliance with the proper use of the soil, and the absence of conservation practices, lead the systems to an unstable use, related to the concept of accelerated erosion. This cycle of unsustainability will eventually lead to physical desertification of some regions accompanied by human desertification of rural communities whose livelihoods, and often survival, are based on agricultural activity [2]. It is imperative not to degrade more than the renewal capacity of this natural resource (soil loss tolerance), or, in other words, the sustainable soil use. Giraldez [3] refers the appreciable importance of water erosion in countries under the influence of Mediterranean climate, mainly due to the long, hot and dry summer period, which makes it difficult to maintain a permanent vegetation cover the soil, and the occurrence of rains in the late summer and, many times, the storms with great erosive potential in autumn.

\section{Characterization of the Erosion Process}

In addition to the effects of water erosion on agricultural fields, the sediments transported by runoff has negative physical and chemical downstream impacts. The first concerns to the excessive levels of turbidity in the receiving waters bodies and the ecological repercussions on aquatic ecosystems [4]. On the other hand, the increase in the rate of sedimentation in bed rivers has a negative impact on the hydraulic characteristics of the natural channels, reducing their depth and favoring the occurrence of floods. The chemical impacts respect to the finest fraction of sediments, mineral and organic colloids. This fraction is responsible for transporting chemicals harmful to the ecological balance of aquatic ecosystems, namely phosphorus, pesticides 
and metals. Some studies refer that much of the organic nitrogen, and more than $90 \%$ of the phosphorus, is transported with the finer fractions of the soil (mainly clay), from the source to the receiving water bodies [5]. Water erosion, with the consequent soil loss, also represents a decrease in the potential for carbon sequestration, which is one of the most important factors that contribute to attenuate the greenhouse effect of the Earth's atmosphere [6].

The most severe erosion will be occurred in the regions where the annual rainfall is between $400-1000 \mathrm{~mm}$, where is included the Mediterranean climate. In this kind of climate, the majority of rainfall is concentrated in four or five months (October, November, December, January and February), matching with scarce vegetation or soil completely unprotected by tillage operations for winter cereals, and causing intense erosion events [1]. To understand better the erosion process, is necessary take present that only the erosive rainfall events (EI30 Index, rainfall erosivity) contribute to the process, and this amount of rainfall depends on the pattern of its distribution along the year. Of course, all of rainfall volume can contribute indirectly to the erosion process, for example by increasing soil moisture, and, in subsequent rain events, generate runoff to lower intensity of rainfall events, or having influence in the stability of soil aggregation [7]. The Figure 1 show the total rainfall and erosive rainfall calculated by Wischmeier and Smith methodology (1978), and average distribution of EI30 factor [8], for fourteen years in the region of center-east of Portugal.
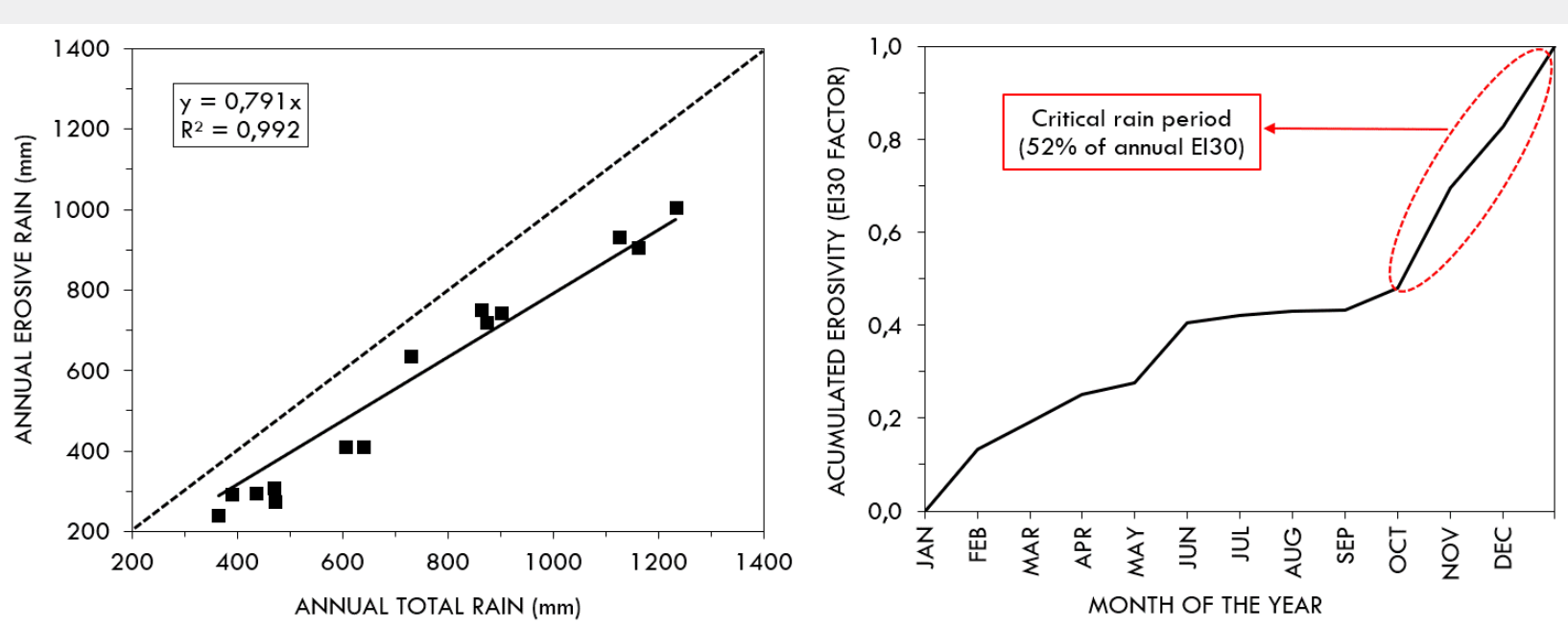

Figure 1: Total rainfall and erosive rainfall calculated by Wischmeier and Smith methodology (1978), and average distribution of EI30 factor [8], for fourteen years (2001-2014) [9].

Despite the rainfall being a factor indispensable and very important in the erosion process, other factors affect the erosion process, some with a decisive important as well, like soil, topography, vegetation and conservation practices. The soil affects the process by its physical (texture, structure) and chemical (organic matter, cation exchange capacity) properties, all of these conjugates to determine two basic properties that influence the resistance of erosion process (soil erodibility), permeability and resistance to disaggregation [7]. The topographic factor includes the hill slope and the hill length. The first affect mainly the velocity and the second affect the volume of runoff, both determining the energy of runoff to detach and transport the soil particles. The vegetation contributes to decrease the intensity of the erosion process, by the protector effect of direct impact of the rain in soil surface, and by lagging effect in runoff by the increase of surface roughness $[10,11]$. The level of these two effects varies strongly according to the kind of crops and natural vegetation, and the specific stage of development. The conservation practices factor includes, obviously, the human activity when conditioning some of the other factors, sometimes conservating and sometimes degrades the soil. In scope of agricultural activity, the challenge is compatible the soil function as a production factor and as a natural resource [12]. The soil use in continuous practice beyond its capacities, will lead to the degradation of its properties and inevitably to a decrease in its resistance to the erosive process [13].

\section{Soil Erosion Under Mediterranean Climate Aggraved by Climate Change Scenario}

In the regions with characteristics of soil and climate verified in the Mediterranean basin, to ensure the sustainable soil use it is decisive the control of soil water erosion, even more in climate change scenarios [14]. Among the effects expected, many authors highlighted the frequency and intensity increase of rainfall events, increasing the risk of water soil erosion intense events. It is as well expectable the frequency and intensity increase of summer heat waves and the associated risk of droughts. Additionally, climate variability and change may have as well significant impacts, not only on the environment, but also in many important socio-economic sectors, such as agriculture, water 
availability, or energy production. These scenarios, conjugated with the aggravation of the soil water erosion process, represent favorable conditions to physical and human desertification of many regions in Mediterranean basin [2]. At the Figure 2a we can see that, in present, many regions of the Mediterranean basin are exposed strongly to soil water erosion, namely the generality of Italy territory, excluding most areas of Apeninos mountain, flatened regions of Po valley and Puglia, some regions of Greece, and almost the totality of Andalucia region in Spain. In the rest of Mediterranean basin, it has other regions with high rates of erosion located at very sloped land (north of Portugal and Pirineus and Alpes mountains). The problem is particularly acute in the region of Andalusia, with high rate of erosion, in most of it occupied by intensive olive orchards and other intensive crops in sloped land and soil unprotected, and in many cases the conditions allow gully erosion with great potential of soil losses [16]. The projection of erosivity factor (EI30 Index, rainfall erosivity) to 2050 relatively 2010 (Figure 2b), as a determining factor of the soil water erosion process, indicates an increasing in some regions where the problem is already worrying (Andalucia-Spain, south of Greece, south of France, and south of Italy), a high increasing (150 - >500MJ $\mathrm{mm} / \mathrm{ha} \mathrm{h} \mathrm{yr)} \mathrm{in} \mathrm{regions} \mathrm{where} \mathrm{the} \mathrm{erosion} \mathrm{rate} \mathrm{is}$ low, but will come very preoccupant if the vegetation disappear in sequence the occurrence of fires, for example (many areas in Iberian Peninsula, and in the generality of Central Europe), and a decreasing in some regions due mainly the decreasing of the annual amount of rainfall (south of Spain, some regions of south of France, and almost the territory of Italy) [17]. It's important to refer that, despite the decreasing of rainfall erosivity in many regions, the problem remain preoccupant since it represents a small fraction of the normal erosivity value.
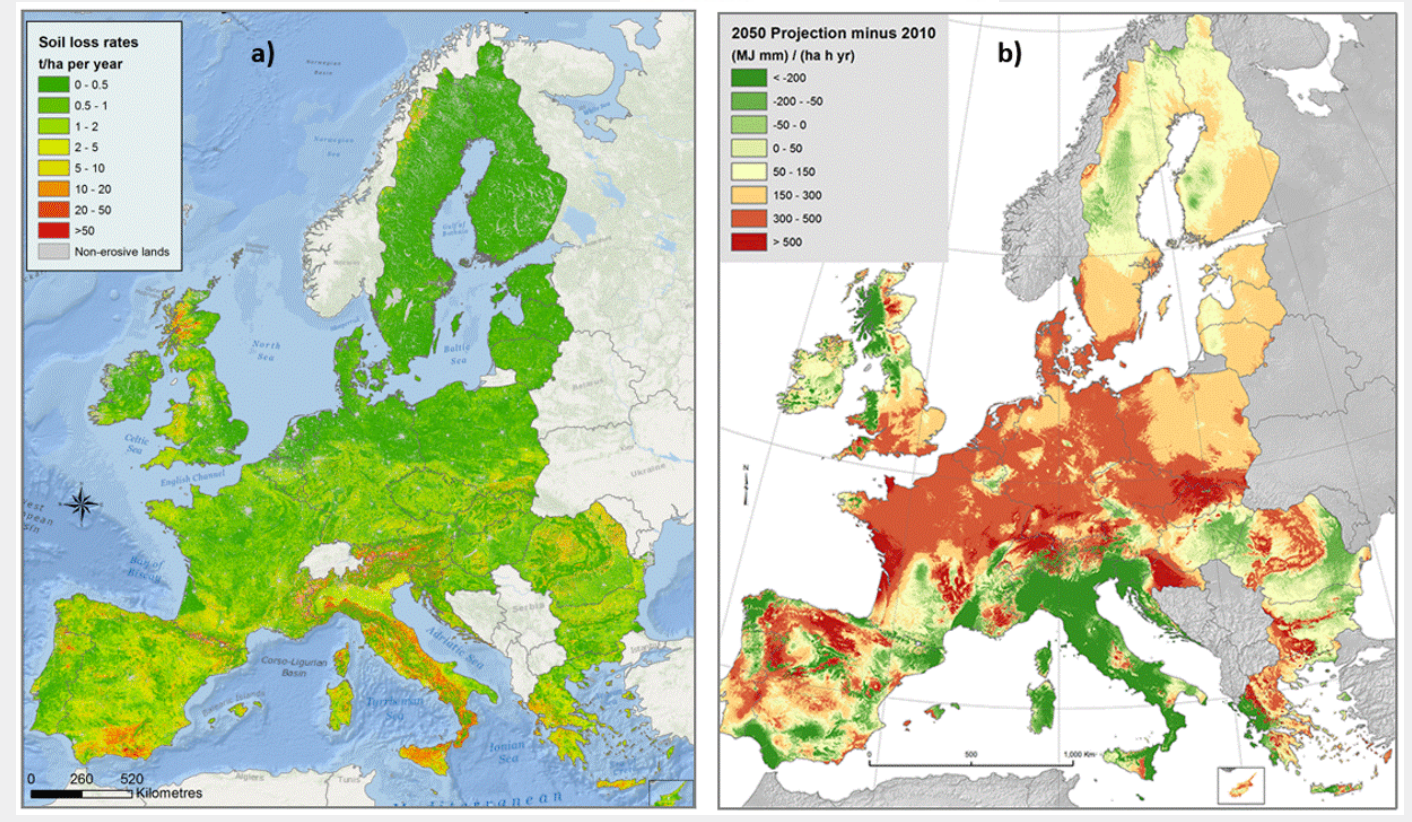

Figure 2: Soil loss by water erosion in European Union at present (a) [15], and absolute difference of rainfall erosivity factor (R-factor) between 2050 projections and 2010 data (b) [17].

How is Possible Prevent and Mitigate the Soil Water Erosion

Soil erosion, as a natural process, cannot be completely nullified, and it is prudent to keep the soil loss compatible with its natural regeneration capacity. With soil conservation practices, it is possible, at the same time, to reduce nutrient losses from agricultural fields and the consequences downstream, such as contamination of the water bodies and sedimentation in rivers bed and reservoirs. The most effective and easiest measures to apply in controlling the process, we highlight those related to the agricultural practices of farmers. These measures, applied at the level of agricultural fields, have as their main objective to prevent the beginning of process, and must be combined with other intervention strategies. Adopted individually by farmers, they do not require works or new equipment, but the change of attitude. The following measures taken by farmers at agricultural fields level, have been shown to be efficient in the control of soil erosion process [11].

\section{Soil protection in the periods when the rainfall is potentially more erosive}

The good soil protection by vegetation (green vegetation or stubble of antecedent crops) can attenuate (detachment of soil particles) or annul the first phase of process. This protection 
is effective if the vegetation well covers the soil, in the period when the rainfall is potentially erosive, in the Mediterranean conditions it happen between October and January or February [9]. The maintenance of a green coverage in the soil during the winter, reduce as well the nitrogen leaching and the transport by superficial runoff [18].

Crop rotations less intensive, according to the soil capacity use, incorporation in the soil the crops stubble

An agricultural system with crop rotation according to the soil capacity use, and adapted a specific climate condition, is necessary to maintain an adequate fertility level. In this point of view, it's important the introduction of leguminous crops, due the improvement of soil structure and the associate physical and chemical properties. After the harvest, the crops stubble left in the soil assure a protection of soil surface and incorporated in the soil contribute to the maintenance or increasing of organic matter levels [19].

\section{Reduction of soil tillage operations}

The soil tillage operations should be reduced to the minimum necessary, matching the advantages of soil conservation and the reduction of the mechanization costs. The excessive tillage operations have a negative direct interference in the destruction of soil structure, that can higher according the soil moisture conditions and the used machinery, and contribute to the soil compaction, as one the biggest problems in the agricultural soils [10]. Additionally, increase the oxidation of organic composts, in soils that, in generally, poor in these components.

\section{Contouring crop operations}

Tillage operations and the remaining crop operations in contouring, create small concavities where the water stay stored and the soil particles stay deposited, therefore an important contribution to increment the water infiltration and, in consequence, decrease the runoff volume [20].

\section{Use of simulation models}

The simulation models, calibrated and validated to specific conditions, are effective tools to reproduce a certain process and its impacts, in this case the soil water erosion. So, it's possible to configurate others alternative situations, with a different conjugation of parameters, and analyze the best results to define codes of good agricultural practices [21]. The Figure 3 shows the results obtained by application of the model AnnAGNPS (Annualized Agricultural Non-Point Source) [23], in a small agroforested basin located at the Centre-east of Portugal. The simulated results are distribution, by sub-basins, of runoff for a time period, and the distribution of soil water erosion rate by sub-basins as well. The relations showed in Figure 3, enable to conclude that there is no correlation between the average sediment production and the average runoff volume in most of the cells in the basin [24]. Although having an influence on the erosion process, the average volume of runoff is not the determining factor. Other factors such as land cover throughout the year, especially during the concentration of rainfall, and the occurrence of more or less erosive storms appear to have more significant influence [25,26].

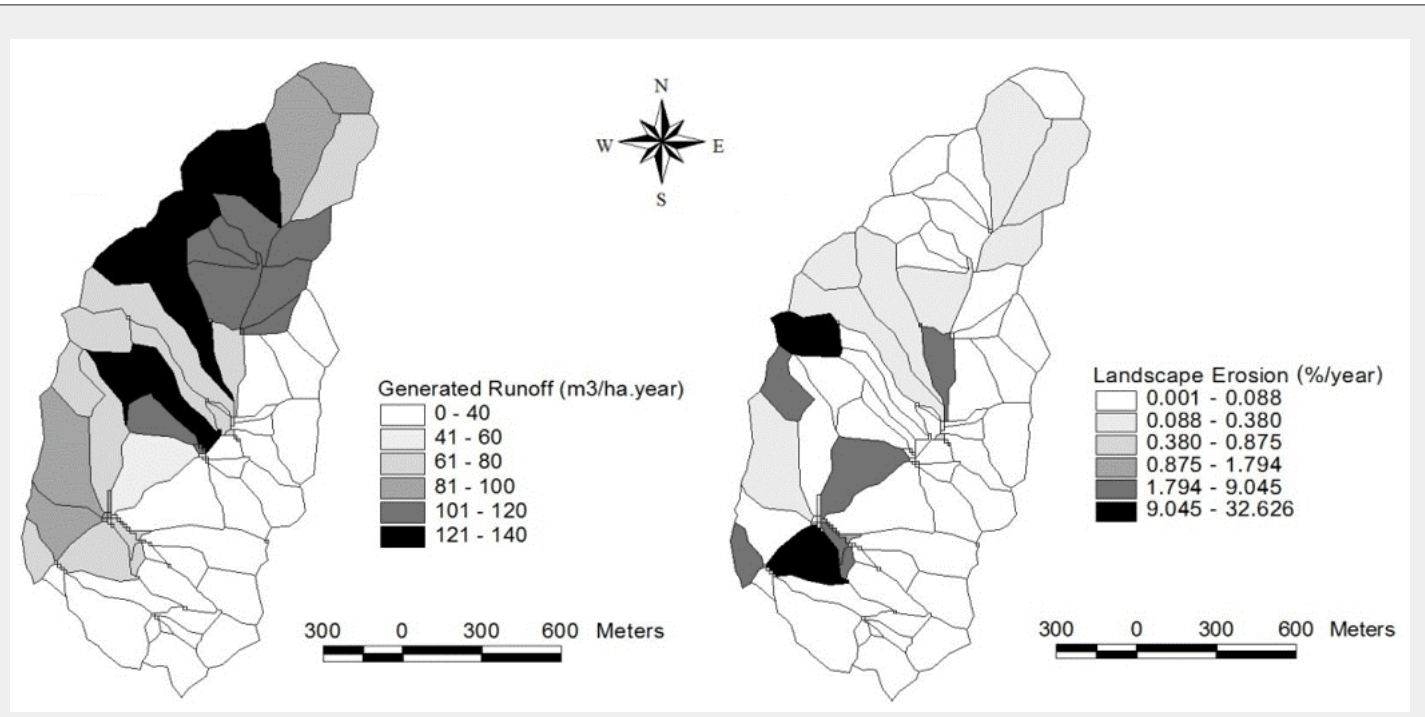

Figure 3: Simulated runoff in an experimental basin, and simulated erosion rate by AnnAGNPS model (Annualized AGricultural Non-Point Source) [22].

\section{Conclusion}

Despite the rainfall being a factor indispensable and very important in the erosion process, other factors affect the erosion process, some with a decisive important as well, like soil, topography, vegetation and conservation practices. Climate variability and change may have as well significant impacts, not only on soil water erosion, but also in many important socio- 
economic sectors, such as agriculture, water availability, or energy production. Many regions of the Mediterranean basin are exposed strongly to soil water erosion, affected mainly by unfavorable climatic conditions, but also by the influence of other factors like the resistance of soils to the process and the agricultural systems. With soil conservation practices, it is possible, at the same time, to reduce nutrient losses from agricultural fields and the consequences downstream, such as contamination of the water bodies and sedimentation in rivers bed and reservoirs. The conservation practices include soil protection in the periods when the rainfall is potentially more erosive, crop rotations less intensive, according the soil capacity use, incorporation in the soil the crops stubble, reduction of soil tillage operations, contouring crop operations. The simulation models, calibrated and validated to specific conditions, are effective tools to reproduce a certain process and its impacts, and configurate others alternative situations, with a different conjugation of parameters, and analyze the best results to define codes of good agricultural practices, as it's demonstrate with the use of AnnAGNPS model.

\section{Acknowledgment}

This work is supported with Portuguese national funds by FCT - Foundation for Science and Technology, I.P., within the GEOBIOTEC - Project UIDB/04035/2020.

\section{References}

1. García-Ruiz J (2010) The effects of land use on soil erosion in Spain: A review. Catena 81(1): 1-11.

2. Verón S, Paruelo JM, Oesterhel M (2006) Assessing desertification. Journal of Arid Environments 66: 751-763.

3. Giráldez J (1998) La erosión del suelo. In: Jiménez Días RM, Lamo de Espinosa J (Eds.), Agricultura Sostenible, Ediciones Mundi-Prensa, Madrid.

4. Gastesi R, Álvarez-Mozos J, De Santisteban LM, Del Valle de Lersundi J, et al. (2008) Runoff, erosion, and water quality of agricultural Casalí J, watersheds in central Navarre (Spain). Agricultural Water Management 95(10): 1111-1128.

5. Troeh F, Hobbs RL, Donahue RL (1999) Soil and Water Conservation Productivity and Environment Protection, Third Edition. Prentice Hall, Upper Saddle River, New Jersey, USA.

6. Lal R (2003) Soil erosion and the global carbon budget. Environment International 29(4): 437-450.

7. Cantón Y, Solé-Benet A, Asensio C, Chamizo S, Puigdefábregas J (2009) Aggregate stability in range sandy loam soils. Relationships with runoff and erosion. Catena 77(3): 192-199.

8. Wischmeier WH, Smith DD (1978) Predicting rainfall erosion lossesAgricultural Handbook No.537. Washington, DC: United States Department of Agriculture.

9. Duarte AC (2017) Vulnerability of soil and water in Mediterranean agro-forestry systems, Chapter 10. In: Mediterranean Identities Environment, Society, Culture, IN-TECH Editor, Rijeka (Croacia), pp. 241-262.

10. Mohammad A, Adam M (2010) The impact of vegetative cover type on runoff and soil erosion under different land uses. Catena 81(2): 97103.

11. Leys A, Govers G, Gillijns K, Berckmoes E, Takken I (2010) Scale effects on runoff and erosion losses from arable land under conservation and conventional tillage: The role of residue cover. Journal of Hydrology 390(3-4): 143-154.

12. Bakker M, Govers G, Kosmas C, Vanacker V, vanOost K, et al. (2005) Soil erosion as a driver of land-use change. Agriculture, Ecosystems \& Environment 105: 467-481.

13. Koulouri M, Giourga C (2007) Land abandonment and slope gradient as key factors of soil erosion in Mediterranean terraced lands. Catena 69(3): 274-281.

14. Eekhout JC, de Vente J (2022) Global impact of climate change on soil erosion and potential for adaptation through soil conservation. EarthScience Reviews 226: 103921.

15. Panagos P, Borrelli P, Poesen J, Ballabio C, Lugato E, et al. (2015) The new assessment of soil loss by water erosion in Europe. Environmental Science \& Policy 54: 438-447.

16. Castillo C, Gómez JA (2016) A century of gully erosion research: Urgency, complexity and study approaches. Earth-Science Reviews 160: $300-319$

17. Panagos P, Ballabio C, Meusburger K, Spinoni J, Alewell C, et al. (2017) Towards estimates of future rainfall erosivity in Europe based on REDES and WorldClim datasets. Journal of Hydrology 548: 251-262.

18. Nunes A, Almeida AC, Coelho C (2011) Impacts of land use and cover type on runoff and soil erosion in a marginal area of Portugal. Applied Geography 31(2): 687-699.

19. Giménez R, Govers G (2008) Effects of freshly incorporated straw residue on rill erosion and hydraulics. Catena 72: 214-223.

20. Du X, Jian J, Du C, Stewart RD (2021) Conservation management decreases surface runoff and soil erosion. International Soil and Water Conservation Research, (in press).

21.Zema DA, Bombino G, Denisi P, Licciardello F, Zimbone SM (2012) Prediction of surface runoff and soil erosion at watershed scale: Analisys of the AnnAGNPS model in different environmental conditions. In: Godone D, Stanchi S (Eds.), Research on Soil Erosion. IN-TECH, Rijeka (Croatia); pp. 4-31.

22. Duarte AC, Ferreira C, Vitali G (2021) Use of simulation models to aid soil and water conservation actions for sustainable agro-forested systems. In: Jhariya MK, Meena RS, Banerjee A, Meena SN (Eds.), Natural Resources Conservation and Advances for Sustainability ELSEVIER (Amsterdam, Netherlands), pp. 389-412.

23. Cronshey RG, Theurer FG (1998) AnnAGNPS-Non-Point Pollutant Loading Model. In Proceedings of First Federal Interagency Hydrologic Modelling Conference, 19-23 April 1998, Las Vegas, NV.

24. Lemunyon JL, Daniel TC (2002) Quantifying phosphorus losses from the agricultural system. Journal of Soil and Water Conservation 57(6): 399-401.

25. Duarte AC, Mateos L, Fereres E (2007) Application of the AnnAGNPS model to a small agricultural watershed, to analyse the spatial and temporal distribution of the pollutants and runoff. In: Proceedings of the 5th International Congress of the European Society for Soil Conservation, 25-28 June, Palermo (Italy).

26. Pathak P, Wani SP, Singh P, Sudi R (2004) Sediment flow behavior from small agricultural watershed. Agricultural Water Management 67: 105-117. 
Your next submission with Juniper Publishers will reach you the below assets

- Quality Editorial service

- Swift Peer Review

- Reprints availability

- E-prints Service

- Manuscript Podcast for convenient understanding

- Global attainment for your research

- Manuscript accessibility in different formats ( Pdf, E-pub, Full Text, Audio)

- Unceasing customer service

Track the below URL for one-step submission https://juniperpublishers.com/online-submission.php 